\title{
Cognitive Based Course Activity: An Opportunity to Enhance Deficient Skills
}

\author{
Kaushik M. ${ }^{1}$ Satish Chikkamath ${ }^{2}$, Nalini C. Iyer ${ }^{3}$ \\ ${ }_{1,2,3}$ Department of Instrumentation Technology, \\ ${ }^{1,2,3}$ B.V. Bhommaraddi College of Enineering \& Technology, Hubli, Karnataka, India \\ 1'Kaushik@bvb.edu, ${ }^{2}$ Chikkamath@bvb.edu, ${ }^{3}$ nalinic@bvb.edu
}

\begin{abstract}
The proposal describes about a course activity designed for sixth semester students of Instrumentation Technology for the course Process Control and Automation. As the activity demands technical,writing and oral presentation skills, students were accordingly grouped based on their capabilities they possess which in turn helps to enhance the other skills they lack. The activity designed focuses on identification and study of programmable logic controllers (PLCs) required in the field of automation, deployment of automation concepts for development of ptototypes and usage of virtual instrumentation tool for implementation of controller principles. This activity has positive effect on personal and interpersonal development of students as well between peer communities. Progress justification can be made by mapping the performance indicators formed for the evaluation of activity with the attainment of program outcomes.
\end{abstract}

Key words: Niddhyaasana, Manana, Adhyayana, Program outcomes, PLCs

\section{Kaushik M.}

Department of Instrumentation Technology,

B.V. Bhommaraddi College of Enineering \& Technology,

Hubli, Karnataka, India

Kaushik@bvb.edu

\section{Introduction}

The term process in an industry refers to a set of well defined sequential tasks to convert raw material into an intended end product. Any and all processes require means $\&$ techniques for the measurement and control of relevant process parameters in-order to achieve higher productivity and reliability at an optimal cost [2]. Thus curriculum design in the instrumentation program facilitates the detailed study of all the phases involved in the process control loop namely sensing phase, signal conditioning phase, process control and automation phase through core theory courses like Electronic Measurements and Instrumentation (EMI), Process Instrumentation (PI), Process Control and Automation (PCA) in the under graduate curriculum at the third, fifth and sixth semester while a laboratory course namely Signal Handling and Data Acquisition (SHDA) in the fourth semester. Activities planned and executed at every level impacts the students with the inter subject relationship and thus strenghtening towards proess automation vertical and enabling students to pursue research and carrier in the same.

The teaching learning approach adopted in the process instrumentation course which involves the detailed study of construction and operating principle of transducers used for the measurement of physical parameters like temperature, pressure, flow, level, displacement, humidity, $\mathrm{pH}$, thickness and to name a few. A field survey followed with design of a novel sensor was given as course activity. This activity 
indeed gave a good exposure towards use of several sensors and transducers adopted in industrial environment. In continuation with this at higher semester level for a course process control and automation which involved introduction to process control elements, controller principles implementation, introduction to automation and PLC operation, PLC programming and instructions, interfacing, concepts of Supervisory Contol And Data Acquisition (SCADA), a course activity was planned such that it addresses diverse course contents as well the diverse skill set of students. In order to help the students, to not only learn the subject effectively but also help them to improve the deficient skills, activity designed emphasised on improving the defienct skills in each of the student. This activity enabled the students not to gain a practical insight into the subject but also the 360 o development of the student.

Activity started with identification of deficienct skills in the students and this identification was done with the detailed analysis of student performance in previous semesters. Based on the cognitive level, students were primarily classified into three categories namely

1. Those students who require strong emphasis on improving writing and presentation skills.

2. Those students who require strong emphasis on improving exploration skills.

3. Those students who require strong emphasis on improving design skill set.

Organization of the paper is as follows, Section 2 deals with the details of enhanced learning process through categorized activities, Section 3 discusses about implementation details and assessment, Section 4 with effectiveness of the activity followed with experimental outcome, discussion and conclusion

\section{Enhanced Learning Through Categorized Activities}

In order to address above three categories of students, three different activities were planned such that each of the activity strongly emphasize on the deficient skills. Another objective of categorized activities includes peer learning amongst communities. Activity details are as follows and detailed description is given in Table1.

Activity 1 is named as Niddhyaasana. The word
Niddhyaasana is derived from Sanskrit which means realization of knowledge in the form of useful product. This activity targeted the students who require improvement in design skill set. In this activity student needs to identify a potential problem in an industry after field survey and then provide solution in the form of prototypes using PLCs as programming device.

Activity 2 is named as Manana. The word Manana in Sanskrit means ability to apply the learnt concepts and verify. This activity targeted the students who require improvement in exploration skills. Student team from this category should consider a physical parameter and should establish a control loop making use of LABVIEW software.

Activity 3 is named as Adhyayana which means thorough study of. This activity targeted the students who require improvement in writing and presentation skills. Thus a detailed study of two different PLC architectures and programming was given.

Table 1 Process Control and Automation course activity details

\begin{tabular}{|c|c|c|c|}
\hline SI.No. & Activity name & $\begin{array}{l}\text { Marks } \\
\text { allotted }\end{array}$ & Deliverables \\
\hline \multirow[t]{3}{*}{1} & \multirow{3}{*}{$\begin{array}{l}\text { Niddhyaasana } \\
\text { (Prototype } \\
\text { implementation) }\end{array}$} & \multirow{3}{*}{40} & $\begin{array}{l}\text { Provide solution in the form } \\
\text { of prototype }\end{array}$ \\
\hline & & & Demonstration \\
\hline & & & Report \\
\hline \multirow[t]{2}{*}{2} & \multirow{2}{*}{$\begin{array}{c}\text { Manana } \\
\text { (Implementation of } \\
\text { controller modes) }\end{array}$} & \multirow[b]{2}{*}{30} & Solve assignments \\
\hline & & & $\begin{array}{l}\text { Implement P,PI,PD,PID } \\
\text { controller technique to } \\
\text { control any physical } \\
\text { parameter }\end{array}$ \\
\hline \multirow[t]{2}{*}{3} & \multirow[t]{2}{*}{$\begin{array}{c}\text { Adhyayana } \\
\text { (Study of PLCs) }\end{array}$} & \multirow[t]{2}{*}{20} & $\begin{array}{l}\text { Detailed presentation on } \\
\text { capabilities of PLCs }\end{array}$ \\
\hline & & & Detailed report \\
\hline
\end{tabular}

The weightages for the above activities were different to make sure that student teams does not miss out any essential component that is part of satisfying the course requirements. In addition to study of PLCs, by Adhyanana teams, to give them the working experience with PLC, they carry out open ended experiment while Manana teams carry out exercise experiment.

\section{Implementation}

This section deals with the details of process execution and assessment methodologies.

Process started with categorization of students and 
team formation. The criterion was students belonging to same category can form a team in number of three or four. A total of eighteen teams for Niddhyaasana, eleven teams for Manana and nine teams for Adhyanana were formed. Scheduling played a very important role to meet the objective of receiving significant help among inter category student teams.

\subsection{Execution process}

Adhyanana teams played an important role during early weeks of semester where they did thorough study of two different PLCs that included its architecture, programming and made a presentation demonstrating the capabilities of the PLCs chosen. In the later weeks they prepared an instructional manual which significantly helps Niddhyaasana students for choosing appropriate PLC for their application and development of prototypes. Some of the PLCs chosen for study were ABB, Allen Bradley, Siemens, Panasonic, Ge Fanuc and Bosch Rexroth.

Manana teams with the knowledge of field survey carried out previously, identified a physical parameter whose control loop with controller principles of Proportional Integral (PI), Proportional Derivative (PD) and Proportional Integral Derivative (PID) was established on a virtual instrumentation platform like LABVIEW. Some of the physical parameters considered were temperature, level and sound. Sample snapshots of virtual instruments (VIs) developed are shown in figure 1.

Niddhyaasana teams who got benefitted from presentations of Adhyanana teams will be able to proceed towards use of PLCs for the development of prototypes that provides a solution for an industrial problem. Some of the best prototypes developed include packaging machine, vegetable chopper, white board cleaner, fruit chopper, colour mixer, paneer making machine and bottle cleaner. Snaps of those are shown in figure 2.

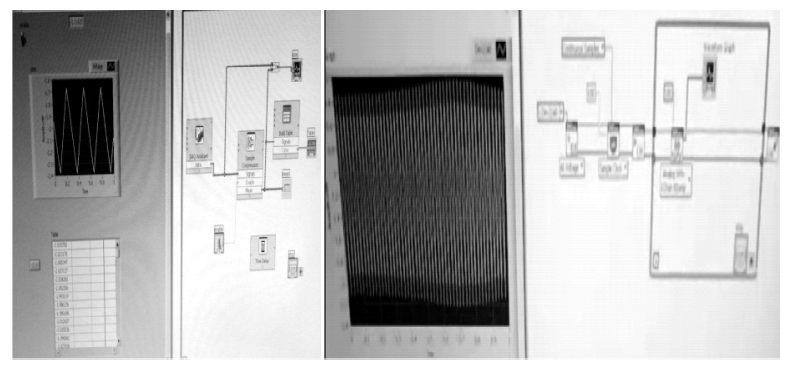

Fig. Virtual Instruments developed on LABVIEW platform as apart of Manana activity

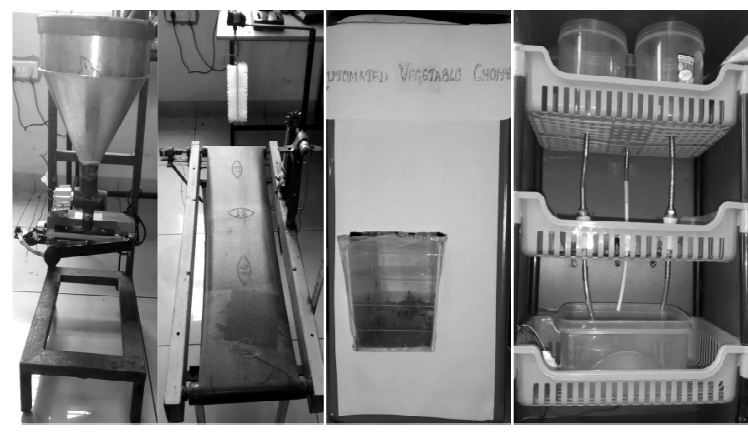

Fig 2. Prototypes samples developed by students as a part of Niddhyaasana activity (a) Packaging machine

b) Bottle cleaner c) Vegetable mixer d) Colour mixer

\subsection{Assessment and Attainments}

Method of assessing the effectiveness of activity includes student performance assessment through minors and course activity and student feedback. Contributions to the activity can be assessed in terms of individual deliverables and group deliverables. The assessment metric/rubric for evaluating the performance of the students based on activity in a community is as shown in table 2, 3 and 4 .

3.3 Reflections of course project through continuous monitoring and feedback

Assessment based on student five point feedback (strongly agree, agree, some what agree, disagree and strongly disagree) has been collected by each team as shown in figure 4.

For question 1, 61\% of students opted strongly agree and $38 \%$ of students opted agree stating that they thoroughly enjoyed the activity. Question 2 related to their choice of activity. Question $3 \& 4$ related to focus of this activity on professional skills where more than $75 \%$ responded positively stating there was good emphasis. Question 6 states that more than $75 \%$ of students agree that their weakness was rightly identified and assigned with appropriate activity.

Table 2 Performance Indicators for Niddhyaasana
\begin{tabular}{|c|l|c|c|c|}
\hline SI.No & Assessment rubric & $\begin{array}{c}\text { PI } \\
\text { code }\end{array}$ & $\begin{array}{c}\text { Weight } \\
\text { age in } \\
\%\end{array}$ & $\begin{array}{c}\text { Attainment } \\
\text { in \% }\end{array}$ \\
\hline 1 & $\begin{array}{l}\text { Ability to apply the } \\
\text { knowledge a3A } \\
\text { mechanical systems. basic }\end{array}$ & 12 & 88.9 \\
\hline 2 & $\begin{array}{l}\text { Ability to apply the } \\
\text { knowledge basic electrical } \\
\text { and electronics }\end{array}$ & a3C & 13 & 98 \\
\hline
\end{tabular}


Table 2 Performance Indicators for Niddhyaasana

\begin{tabular}{|c|c|c|c|c|}
\hline Sl.No & Assessment rubric & $\begin{array}{c}\text { PI } \\
\text { code }\end{array}$ & $\begin{array}{l}\text { Weight } \\
\text { age in } \\
\%\end{array}$ & $\begin{array}{l}\text { Attainment } \\
\text { in } \%\end{array}$ \\
\hline 3 & $\begin{array}{l}\text { Ability to apply theoretical } \\
\text { concepts for the design of } \\
\text { experiment }\end{array}$ & $\mathrm{b} 1 \mathrm{~A}$ & 13 & 96 \\
\hline 4 & $\begin{array}{l}\text { Ability to select appropriate } \\
\text { component, equipment, test } \\
\text { apparatus or model. }\end{array}$ & $\mathrm{b} 1 \mathrm{C}$ & 12 & 91.07 \\
\hline 5 & $\begin{array}{l}\text { Ability to express the given } \\
\text { system behavior as a } \\
\text { function of variables. }\end{array}$ & b1D & 7 & 95.53 \\
\hline 6 & $\begin{array}{l}\text { Ability to Select \& use } \\
\text { appropriate device/ sensor/ } \\
\text { method for the measurement } \\
\text { of parameters }\end{array}$ & $\mathrm{b} 2 \mathrm{C}$ & 7 & 89.8 \\
\hline 7 & $\begin{array}{l}\text { Ability to develop a } \\
\text { circuit/algorithm. }\end{array}$ & $\mathrm{c} 4 \mathrm{~A}$ & 13 & 97.8 \\
\hline 8 & $\begin{array}{l}\text { Ability to verify the } \\
\text { desired functionality. }\end{array}$ & $\mathrm{c} 4 \mathrm{~B}$ & 7 & 91.3 \\
\hline 9 & $\begin{array}{l}\text { Ability to validate the } \\
\text { obtained results. }\end{array}$ & $\mathrm{c} 4 \mathrm{C}$ & 7 & 87.3 \\
\hline 10 & $\begin{array}{l}\text { Awareness about the } \\
\text { importance of learning } \\
\text { beyond curriculum using } \\
\text { technical library resources, } \\
\text { interacting with experts } \\
\text { and participating in } \\
\text { technical events. }\end{array}$ & ilA & 5 & 98 \\
\hline 11 & $\begin{array}{l}\text { Importance of learning } \\
\text { beyond curriculum using } \\
\text { technical library resources, } \\
\text { interacting with experts } \\
\text { and participating in } \\
\text { technical events. }\end{array}$ & $\mathrm{ilC}$ & 4 & 98 \\
\hline
\end{tabular}

Table 3 Performance Indicators for Manana

\begin{tabular}{|c|c|c|c|c|}
\hline Sl.No & Assessment rubric & $\begin{array}{c}\text { PI } \\
\text { code }\end{array}$ & $\begin{array}{l}\text { Weight } \\
\text { age in } \\
\%\end{array}$ & $\begin{array}{l}\text { Attainment } \\
\text { in } \%\end{array}$ \\
\hline 1 & $\begin{array}{l}\text { Ability to apply the } \\
\text { knowledge } \\
\text { mechanical systems. }\end{array}$ & $\mathrm{a} 3 \mathrm{~A}$ & 10 & 73.3 \\
\hline 2 & $\begin{array}{l}\text { Ability to apply the } \\
\text { knowledge basic electrical } \\
\text { and electronics }\end{array}$ & $\mathrm{a} 3 \mathrm{C}$ & 17 & 73.6 \\
\hline 3 & $\begin{array}{l}\text { Ability to select } \\
\text { appropriate component, } \\
\text { equipment, test apparatus, } \\
\text { model etc. }\end{array}$ & $\mathrm{b} 1 \mathrm{C}$ & 17 & 75.2 \\
\hline 4 & $\begin{array}{l}\text { Ability to select \& use } \\
\text { appropriate device/ sensor/ } \\
\text { method for the } \\
\text { measurement } \\
\text { parameters }\end{array}$ & $\mathrm{b} 2 \mathrm{C}$ & 6 & 62 \\
\hline 5 & $\begin{array}{l}\text { Ability to develop a } \\
\text { circuit/algorithm. }\end{array}$ & $\mathrm{c} 4 \mathrm{~A}$ & 6 & 76 \\
\hline 6 & $\begin{array}{l}\text { Ability to verify the } \\
\text { desired functionality. }\end{array}$ & $\mathrm{c} 4 \mathrm{~B}$ & 13 & 75 \\
\hline
\end{tabular}

\begin{tabular}{|c|l|c|c|c|}
\hline 7 & $\begin{array}{l}\text { Ability to validate the } \\
\text { obtained results. }\end{array}$ & $\mathrm{c}$ C & 6 & 72 \\
\hline 8 & $\begin{array}{l}\text { Ability to define roles and } \\
\text { responsibilities of team } \\
\text { members }\end{array}$ & $\mathrm{d} 1 \mathrm{~A}$ & 6 & 82 \\
\hline 9 & $\begin{array}{l}\text { Ability to write clear and } \\
\text { well organizes project } \\
\text { reports. }\end{array}$ & $\mathrm{g} 1 \mathrm{~A}$ & 17 & 36.8 \\
\hline
\end{tabular}

Table 4 Performance Indicators for Adhyanana

\begin{tabular}{|c|c|c|c|c|}
\hline Sl.No & Assessment rubric & $\begin{array}{c}\text { PI } \\
\text { code }\end{array}$ & $\begin{array}{c}\text { Weight } \\
\text { age in \% }\end{array}$ & $\begin{array}{l}\text { Attainment } \\
\text { in } \%\end{array}$ \\
\hline 1 & $\begin{array}{l}\text { Ability to define roles } \\
\text { and responsibilities of } \\
\text { team members }\end{array}$ & $\mathrm{dlA}$ & 10 & 73.8 \\
\hline 2 & $\begin{array}{l}\text { Ability to take } \\
\text { leadership roles as need } \\
\text { arises to accomplish the } \\
\text { team }\end{array}$ & $\mathrm{d} 1 \mathrm{~B}$ & 10 & 69 \\
\hline 3 & $\begin{array}{l}\text { Ability to contribute } \\
\text { effectively to the team } \\
\text { discussions. }\end{array}$ & dlD & 10 & 71.4 \\
\hline 4 & $\begin{array}{l}\text { Ability to write clear } \\
\text { and well organizes } \\
\text { project reports. }\end{array}$ & g1A & 25 & 50.4 \\
\hline 5 & $\begin{array}{l}\text { Ability to present the } \\
\text { results, conclusions and } \\
\text { future scope. }\end{array}$ & $\mathrm{glC}$ & 10 & 69.04 \\
\hline 6 & $\begin{array}{l}\text { Ability to prepare } \\
\text { presentation using visual } \\
\text { aids. }\end{array}$ & g2A & 10 & 66.6 \\
\hline 7 & $\begin{array}{l}\text { Ability to deliver an } \\
\text { effective presentation. }\end{array}$ & g2B & 25 & 56.1 \\
\hline
\end{tabular}

Attainment of performance indicators through minors is shown in figure 3 .

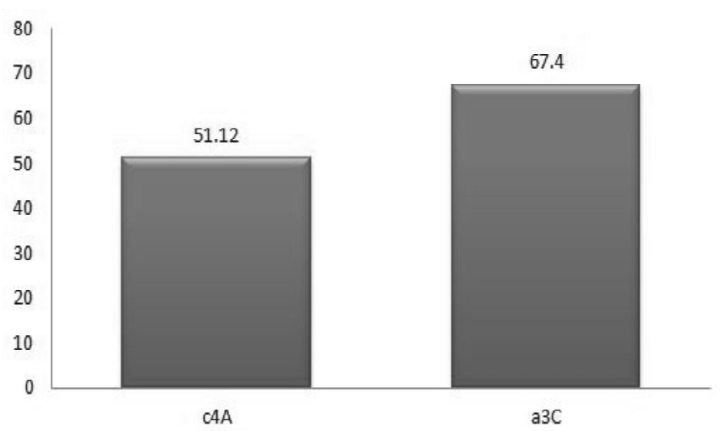

Fig. 3 PI attainments through minors 


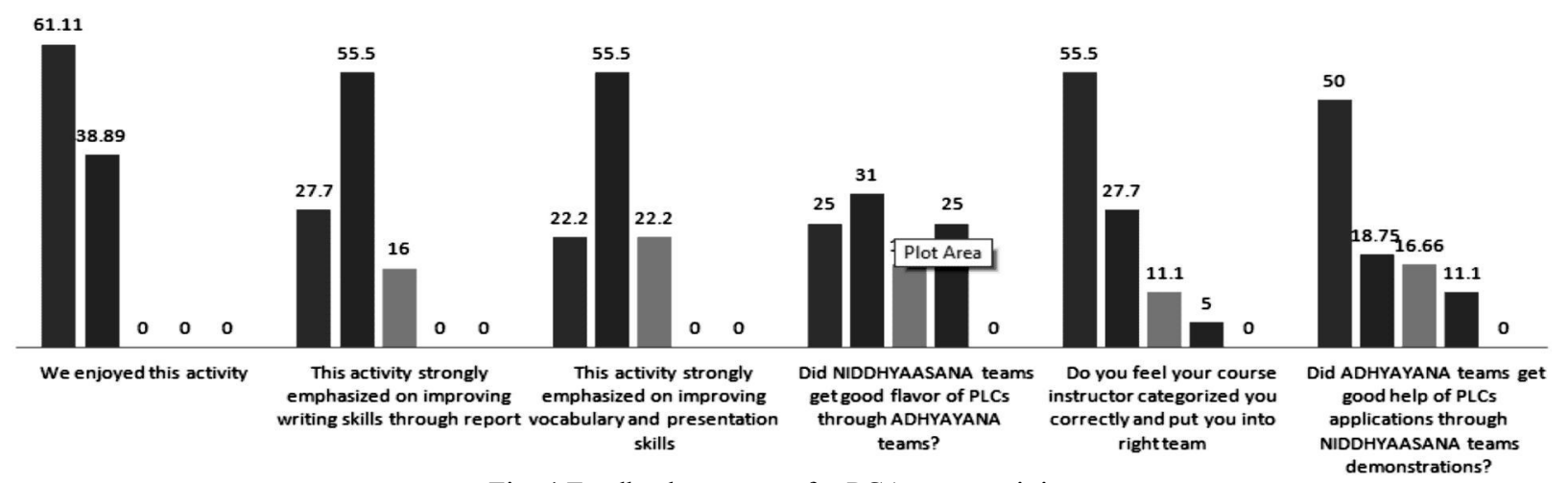

Fig. 4 Feedback response for PCA course activity

\section{Conclusion}

The details of the activity planned and executed for the subject Process control and Automation according to the student competencies to enhance the learning outcome and achieve $360 \mathrm{o}$ development of students have been presented. The metrics and the techniques adopted for the assessment of the learning outcome have been listed and the results are presented.

The overall outcome significantly encourages in terms of the holistic student development.The most prominent positive outcome of the experiment is that all three communities of stuents thoroughly enjoyed the activity assigned to them. However through experience as well feedback it is found that there is scope for improvement in terms peer to peer learning amongst communities.

\section{References}

[1] Kaushik M, Preeti Nalini C Iyer, 'Prototype implementation: an effective method in process automation', Journal of Engineering Education Transformations volume $28 \mathrm{n}$ no 2 and 3 , Oct 2014 and Jan 2015

[2] Nalini C Iyer, Kaushik M, 'An Experiment on Enhanced Learning through Field Exercise' , Proceedings of IEEE MITE 2013 International conference on MOOC, Innovation and Technology in Education pg 532013

[3] Jennifer M. Case , Gregory Light, 'Emerging Methodologies in Engineering Education Research' Journal of Engineering Education January 2011, Vol. 100, No. 1, pp. 186-210

[4] Edward F. Redish, Karl A. Smithg 'Looking Beyond Content:Skill Development For Engineers' unpublished
[5] Caroline Baillie, Jonte Bernhard, ' Educational Research Impacting Engineering Education unpublished

[6] Richard M. Felder, Donald R. Woods, James E. Stice, Armando Rugarcia , 'The Future Of Engineering Education; Teaching Methods That Work' Chem. Engr. Education, 34(1), 26-39 (2000).

[7] Janis Swan and Elizabeth Godfrey, 'Sustained improvements in teaching and learning in Engineering Education' A Research Report, University of Waikato

[8] Bhavya Lal, 'Strategies for Evaluating Engineering Education Research', Workshop Report unpublished

[9] Linda P.B. Katehi, Katherine Banks, Heidi A. Diefes-Dux, Deborah K. Follman, John Gaunt, Kamyar Haghighi, P.K. Imbrie, Leah H. Jamieson, Robert E. Montgomery, William C. Oakes, and Phillip Wankat, 'A New Framework for Academic Reform in Engineering Education' ,Proceedings of the 2004 American Society for Engineering Education Annual Conference \& Exposition

[10] Motoei Azuma, François Coallier, Juan Garbajosa, 'How to Apply the Bloom Taxonomy to Software Engineering', Proceedings of the Eleventh Annual International Workshop on Software Technology and Engineering Practice, 2004

[11] http://www.abet.org/special-reports/

[12] The University of Wisconsin-Madison http://teachingacademy.wisc.edu/archive/Assist ance/course/blooms.htm

[13] Laury Bollen, Boudewijn Janssen, Wim Gijselaers, 'Measuring the effect of innovations in teaching methods on the performance of 
accounting students'

[14] http://cft.vanderbilt.edu/teachingguides/pedagogical/blooms-taxonomy/

[15]http://ww2.odu.edu/educ/roverbau/Bloom/bloo ms_taxonomy.htm

[16]http://www.unco.edu/cetl/sir/stating_outcome/d ocuments/Krathwohl.pdf

[17]http://www4.ncsu.edu/unity/lockers/users/f/feld er/public/Papers/Prince_AL.pdf

[18] Michael Prince, 'Does Active Learning Work? A Review of the Research', Journal of Engineering
Education, July 2004, pp.1-9.

[19] Nancy Van Note Chism,Elliot Douglas, Wayne J. Hilson, Jr, 'Qualitative Research Basics: A Guide for Engineering Educators', Rigorous Research in Engineering Education NSF DUE-0341127, 2008

[20] W.H. E Maraghy, 'Future Trends in Engineering Education and Research', Advances in Sustainable Manufacturing: Proceedings of the 8th Global Conference on Sustainable Manufacturing, pp. 11-16 